\title{
Efikasi Bakasang sebagai imunostimulan pada pakan sidat (Anguilla marmorata) terhadap infeksi Aeromonas hydrophila
}

(The Efficacy of fish silage (Bakasang) as immunostimulant in eel (Anguilla marmorata) feed against Aeromonas hydrophila Infection)

\author{
Olvi A.P Janis ${ }^{1}$, Reiny A. Tumbol ${ }^{2}$, Sammy Longdong ${ }^{2}$ \\ 1) Mahasiswa Program Studi Budidaya Perairan, FPIK UNSRAT Manado \\ Email: olvianggraeni@ymail.com \\ 2) Staff pengajar Progran Studi Budidaya Perairan,FPIK UNSRAT Manado \\ Email: reinytumbol@yahoo.com
}

\begin{abstract}
The purpose of this study was to examine the effect of fish silages, bakasang as an immunostimulant in eel (Anguilla marmorata) feed against Aeromonas hydrophila infection. Three hundred elvers with the size of $\pm 10 \mathrm{~cm}$ taken from Freshwater Aquaculture Institute (BBAT) Tatelu. The elvers were placed into 4 glass aquarium, each equipped with aerator and 1 for stock. Prior to the study, the eels were acclimatized for two weeks in order to adapt to new environmental condition. Two sets of researches were done: feeding the eels with additional bakasang with different doses for 6 weeks, which then further were challenged with Aeromonas hydrophila by immersion method. This study used a completely randomized design (CRD) with 4 treatments A (0 mL $/ \mathrm{kg}$ diet), B (50 mL/kg diet), C (100 mL/kg diet), D (150 mL/kg diet). The growth data was taken by measuring the weight and length of the eels at the end of the period of feeding treatment while the mortality data of the eels were observed for 10 days after challenge test. The results of analysis of variance showed that the resistance of the eels in treatment $B(50 \mathrm{~mL} / \mathrm{kg}$ diet $), C(100 \mathrm{~mL} / \mathrm{kg}$ diet $)$ and $\mathrm{D}(150 \mathrm{~mL} / \mathrm{kg}$ diet) significantly different compared with treatment A. However, among the treatments $\mathrm{B}, \mathrm{C}$ and $\mathrm{D}$, there were no significant differences. Furthermore, the best eel growth was observed in treatment B with an absolute growth of $1.14 \mathrm{~g}$, followed by treatment of $\mathrm{D}$ with an absolute growth of $1.04 \mathrm{~g}$. In treatment $\mathrm{A}$ the absolute growth was only $0.82 \mathrm{~g}$ while treatment $\mathrm{C}$ was $0.88 \mathrm{~g}$. This suggests that the addition of bakasang in eels feed can promote the growth of eels as well as resistance against pathogen infection, thus served as immunostimulant.
\end{abstract}

Keywords: fish silages, immunostimulant, eel, Aeromonas hydrophila, growth

\section{PENDAHULUAN}

Sidat merupakan salah satu komoditas ekspor perikanan yang memiliki nilai ekonomis tinggi dan permintaan global yang semakin meningkat (Sidatmoa, 2009). Salah satu spesies yang memiliki nilai ekonomis tinggi adalah (Anguilla marmorata). Permintaan pasar dunia akan sidat semakin populer, menyebabkan harga jual sidat semakin mahal. 
Upaya pengembangan budidaya sidat secara intensif, penyediaan benih yang berkualitas dalam jumlah besar dan secara terus menerus merupakan faktor yang penting. Selain itu kualitas air, pakan, penanggulangan penyakit dan penerapan teknologi budidaya yang tepat juga perlu diperhatikan (Matsui dalam Koroh dan Lumenta, 2014). Berbagai kegiatan intensifikasi budidaya sidat sudah banyak dikembangkan, namun serangan penyakit merupakan permasalahan utama yang dapat mengancam kelangsungan hidup sidat karena dapat menyebabkan kematian elver dalam jumlah besar (Jefriansyah, 2009).

Untuk itu, cara efektif dalam upaya pencegahan penyakit yakni dengan penggunaan bahan-bahan yang bersifat imunostimulan yang merupakan bahan materi biologis dan/atau zat sintesis yang dapat meningkatkan aktivitas pertahanan non spesifik serta merangsang organ pembentuk antibiotik dalam tubuh untuk bekerja secara maksimal. Salah satu contoh yakni penggunaan bakteri probiotik dalam pakan ikan yang dapat meningkatkan pertumbuhan dan fungsi kekebalan tubuh ( Gatesoupe et al.,1999 ). Beberapa jenis bakteri menguntungkan telah dan sementara dikembangkan sebagai probiotik diantaranya jenis-jenis Bakteri Asam Laktat ( BAL ) seperti lactobacillus, Pseudomonas, Streptococus, Micrococus ( Ijong dan Ohta, 1996 ), Lactobacillus acidophilus, Lactobacillus plantarum dan Streptococusfaecalis ( Yanti, 2009) dan Lactobacillus acidophilus dan Lactobacillus plantarum serta Bifidobacterium sp ( Ingratubun et al., 2013 ) yang terkandung di dalam bahan hasil fermentasi jeroan ikan yang dikenal dengan Bakasang. BAL dapat hidup dan tumbuh di dalam saluran pencernaan, aktifitas dan produk metabolit yang di hasilkan BAL di dalam saluran pencernaan dapat merangsang aktivitas sistem kekebalan tubuh (Pangaribun dkk., 2013).

Kandungan BAL dalam bakasang menjadikan bahan ini berpotensi untuk digunakan sebagai bahan tambahan pakan ikan/ternak yang dapat berfungsi sebagai bahan pemicu pertahanan tubuh terhadap penyakit (sistem imun) atau lebih dikenal dengan istilah "Imunostimulan". Imunostimulan merupakan suatu materi biologis dan zat sintesis yang dapat meningkatkan aktivitas pertahanan non spesifik serta merangsang organ pembentuk antibodi dalam tubuh untuk bekerja secara maksimal (Anderson, 1992).

Penggunaan bakasang sebagai bahan imunostimulan telah dilakukan dalam penelitian pada ikan Nila (Oreochromis niloticus) dan Sidat (Anguilla marmorata) (Pangaribuan, dkk., 2013 dan Pinoke, dkk., 2015). Pemberian tambahan bakasang memperlihatkan peningkatan sistem imun non spesifik yang ditandai dengan meningkatnya total leukosit serta aktivitas fagostitosis.

Dari penelitian-penelitian terdahulu yang sudah dilakukan oleh Pangaribuan, $d k k$ (2015) dan Pinoke, dkk (2015) memperlihatkan bahwa pemanfaatan bakasang sebagai imunostimulan mempunyai potensi besar untuk dikembangkan bukan saja dalam upaya pencegahan penyakit tetapi untuk peningkatan pertumbuhan organisme budidaya seperti sidat. Penggunaan produk samping sumberdaya ikan ini akan sangat menguntungkan bagi petani ikan. Oleh sebab itu dari uraian di atas, perlu dilakukan penelitian untuk mengetahui pengaruh penambahan bakasang sebagai 
bahan imunostimulan pada pakan sidat (Anguilla marmorata) terhadap infeksi bakteri Aeromonas hidrophila

\section{METODE PENELITIAN}

\section{Alat dan bahan}

Alat dan bahan yang digunakan dalam penelitian ini adalah sebagai berikut : akuarium sebanyak 5 buah dan toples 12 buah, serta perlengkapannya berupa aerator, serok dan peralatan laboratorium .

Bahan penelitian yang digunakan yaitu :

- Bahan imunostimulan yang digunakan adalah bakasang yang didapatkan dari pasar swalayan yang ada di kota Manado.

- $\quad$ Pakan Sidat : Pakan yang digunakan adalah pakan provite 781 yang didapatkan dari BBAT Tatelu dalam bentuk bubuk. Pakan sidat bentuk bubuk ini selanjutnya diubah menjadi bentuk pasta mengingat sidat ukuran elver ini lebih menyukai pakan berbentuk pasta. Untuk mendapatkan bentuk pasta, pertamatama pakan dalam bentuk bubuk di timbang sebanyak 100 gram tiap perlakuan untuk 3 hari pemberian makanan. Menurut Pangaribun (2015), Bakteri Asam Laktat paling tinggi dalam bakasang terdapat $10^{5}$ CFU BAL/ml. Untuk mendapatakan dosis bakasang tiap perlakuan yaitu 100 gr +0 bakasang untuk perlakuan A (0 mL/kg pakan), $100 \mathrm{~g}$ + $5 \mathrm{~mL}$ bakasang untuk perlakuan B (50 mL/kg pakan), dan $100 \mathrm{~g}+10$ $\mathrm{mL}$ untuk perlakuan C $(100 \mathrm{~mL} / \mathrm{kg}$ pakan) dan $100 \mathrm{~g}+15 \mathrm{~mL}$ bakasang untuk perlakuan D $(150 \mathrm{~mL} / \mathrm{kg}$ pakan). Bakasang yang sudah diambil sesuai dosis yang diperlukan kemudian dicampur dengan pakan dalam bentuk bubuk lalu tambahkan sedikit air agar tercampur secara merata selanjutnya buat dalam bentuk pasta. Kemudian pakan yang sudah berbentuk pasta dikeringanginkan. Pakan selanjutnya dimasukan dalam kantong plastik dan disimpan dilemari pendingin sampai saat yang digunakan.

- Hewan Uji : Sidat (elver) yang diambil dari Balai Budidaya Air Tawar (BBAT) Tatelu. Banyaknya sidat yang diambil adalah 300 ekor dengan ukuran $\pm 10 \mathrm{~cm}$.

- Bakteri Patogen : Bakteri yang digunakan adalah Aeromonas hydrophilla yang berasal dari Laboratorium Balai Budidaya Air Tawar (BBAT) Tatelu.

\section{Prosedur Penelitian}

Hewan uji dimasukan kedalam 2 Akuarium yang tiap akuarium memiliki sekat sehingga terbagi 2 dan 1 akuarium digunakan sebagai stok. Sebelum pelaksanaan perlakuan sidat diaklimatisasi terlebih dahulu selama 2 minggu agar dapat beradaptasi dengan kondisi lingkungan hidup yang baru. Dalam proses aklimatisasi setiap akuarium dilengkapi dengan aerator. Sidat diberi pakan pelet terlebih dahulu dan diberikan 2 kali per hari yaitu pukul 09.00 dan17.00. Untuk menjaga agar kualitas air tetap baik maka dilakukan penggantian air sebanyak 30\% setiap 2-3 hari sekali tergantung pada kondisi air.

Setelah proses aklimatisasi selesai, kepadatan sidat diatur menjadi 30 ekor per akuarium. Sidat diberi pakan perlakuan dengan dosis 3\%/bb/hari dengan frekuensi pemberian 2x sehari yaitu pagi (09.00) 
dan sore (17.00). Sidat diberi perlakuan pakan uji selama 6 minggu berturut-turut. Selama percobaan berlangsung kualitas air akan dikontrol agar tetap baik.

Dua set penelitian dilakukan yakni pemberian pakan dengan tambahan bakasang dengan dosis berbeda dan selanjutnya akan dilakukan uji tantang terhadap sidat yang telah diberi pakan perlakuan selama 6 minggu. Perlakuan yang akan digunakan adalah dosis bakasang. Berdasarkan hasil penelitian terdahulu (Pinoke, $d k k$., 2015), dosis yang efektif adalah $100 \mathrm{~mL} / \mathrm{kg}$, sedangkan dosis $50 \mathrm{~mL} / \mathrm{kg}$ tidak memberikan hasil yang berbeda nyata dengan pakan tanpa bakasang; dosis $150 \quad \mathrm{~mL} / \mathrm{kg}$ memperlihatkan hasil yang sama dengan dosisi $100 \mathrm{~mL} / \mathrm{kg}$. Atas dasar ini , maka penelitian ini akan menggunakan rancangan acak lengkap (RAL) dengan 4 jenis perlakuan A (0 mL/kg pakan), B (50 $\mathrm{mL} / \mathrm{kg}$ pakan ), C (100 mL/kg pakan), D (150 mL/kg pakan). Pengambilan data hasil uji tantang akan dilakukan setelah 6 minggu masa pemeliharaan, sidat akan diinfeksi dengan bakteri A. hydrophilla.

\section{Uji Tantang}

Bakteri uji yang digunakan adalah Aeromonas hydrophilla yang diperoleh dari Laboratorium Balai Budidaya Air Tawar (BBAT) Tatelu. Uji tantang dilakukan pada sidat yang dipelihara selama 6 minggu yang diberi pakan perlakuan.

Wadah yang disiapkan untuk uji tantang adalah toples 12 buah yang dilengkapi dengan aerasi dan diisi air sebanyak $500 \mathrm{~mL}$. Setiap toples yang sudah disiapkan akan diisi sidat yang diambil dari wadah perlakuan dan tiap-tiap perlakuan diambil 12 ekor sidat yang dibagi dalam 3 toples, masing-masing 4 ekor tiap toples. Sidat diinfeksi dengan bakteri Aeromonas hydrophilla dengan kepadatan bakteri $10^{8}$. Untuk mendapatkan kepadatan bakteri yang dipakai pada uji tantang yaitu ambil stok bakteri A. hydrophilla dengan menggunakan jarum ose lalu masukan ke tabung reaksi dalam $9 \mathrm{~mL}$ air steril sehingga kepadatan bakteri menjadi $10^{9}$, selanjutnya kocok sampai keruh/tidak transparan, ambil pipet $1 \mathrm{~mL}$ kemudian campur dalam $9 \mathrm{~mL}$ air sehingga diperoleh kepadatan bakteri $10^{8}$. Kemudian diinfeksi ke sidat selama 9 jam.

\section{Pertumbuhan}

Data pertumbuhan sidat diukur pada minggu kedua dan keenam yang sudah diberikan perlakuan. Pertama-tama sidat diambil dari akuarium sebanyak 5 ekor per perlakuan dengan menggunakan seser (sibu-sibu) dan dipindahkan dalam loyang, sidat selanjutnya ditimbang.

Pertumbuhan sidat yang diukur adalah pertumbuhan mutlak yaitu selisih antara berat sidat yang diukur pada akhir penelitian dan berat awal ikan. Pertumbuhan mutlak dihitung dengan menggunakan rumus sebagai berikut (Effendie, 1979).

$$
\Delta \mathrm{G}=\mathrm{Wt}-\mathrm{Wo}
$$

Dimana :

$$
\begin{aligned}
& \Delta \mathrm{G}=\text { Pertumbuhan }(\mathrm{g}) \\
& \mathrm{Wt}=\text { Berat ikan pada waktu } \mathrm{t}(\mathrm{g}) \\
& \mathrm{Wo}=\text { Berat ikan pada awal } \\
& \text { percobaan }(\mathrm{g})
\end{aligned}
$$

Dari data yang dipeoleh dalam penelitian ini maka dilakukan analisa data dengan menggunakan Rancangan Acak Lengkap dengan menggunakan program statistik JMP. Untuk mengevaluasi pengaruh penambahan bakasang terhadap infeksi bakteri aeromonas hydrophila. 


\section{HASIL DAN PEMBAHASAN}

Hasi Analisis ragam menunjukan bahwa Perlakuan B, C dan D berbeda sangat nyata dibandingkan dengan perlakuan A. Namun demikian, antara perlakuan B,C dan D tidak terdapat perbedaan nyata. Hal ini memperlihatkan bahwa penambahan bakasang dalam pakan sidat mempengaruhi pertumbuhan serta kemampuan bertahan terhadap penyakit/infeksi Aeromonas hydrophila. Dosis bakasang yang dicobakan $(50 \mathrm{~mL} / \mathrm{kg}$ pakan, $100 \mathrm{~mL} / \mathrm{kg}$ pakan dan $150 \mathrm{~mL} / \mathrm{kg}$ pakan) tidak memperlihatkan perbedaan yang nyata. Perbedaan dosis yang dicobakan ini tidak cukup untuk memberikan perbedaan satu dengan yang lain.

Hasil uji tantang dengan bakteri $A$. hydrophila pada sidat yang telah diberi perlakuan selama 42 hari menunjukkan bahwa pemberian pakan bakasang terlihat memberikan efek perlindungan terhadap infeksi A.hydrophila terutama pada sidat yang diberi pakan dengan dosis $100 \mathrm{~mL} / \mathrm{kg}$ dan $150 \mathrm{~mL} / \mathrm{kg}$. Sampai hari 10 setelah diinfeksi bakteri Aeromonas hydrophila yang mati adalah 13 ekor yaitu pada perlakuan A yang mati 9 ekor, sedangkan pada C yang mati 2 ekor . Pada perlakuan C tidak ditemukan ikan yang mati. Kematian sidat pada uji tantang dengan bakteri A. hydrophila ini membuktikan bahwa sidat tersebut memiliki daya tahan yang kurang baik untuk merespons masuknya patogen. sidat yang diberi pakan tanpa campuran bakasang, tetapi pada 3 perlakuan yang diberi pakan campuran bakasang mempunyai sistem kekebalan yang cukup baik karena dapat bertahan hidup walaupun pada bagian operculum, insang dan bagiaan tubuh terlihat bercak merah. Rendahnya jumlah kematian sidat pada perlakuan B dan D dalam pakan memiliki kemampuan untuk meningkatkan imunitas pada sidat.

Tabel. 1. Kelangsungan hidup sidat pada tiap perlakuan

\begin{tabular}{|c|c|c|c|}
\hline Perlakuan & Mati & Hidup & Kelangsungan Hidup (\%) \\
\hline A1 & 3 & 1 & 25 \\
\hline A2 & 3 & 1 & 25 \\
\hline A3 & 3 & 1 & 25 \\
\hline B1 & 0 & 4 & 100 \\
\hline B2 & 0 & 4 & 100 \\
\hline B3 & 2 & 2 & 50 \\
\hline C1 & 0 & 4 & 100 \\
\hline C2 & 0 & 4 & 100 \\
\hline C3 & 0 & 4 & 100 \\
\hline D1 & 0 & 4 & 100 \\
\hline D2 & 0 & 4 & 100 \\
\hline D3 & 2 & 2 & 50 \\
\hline
\end{tabular}

Sidat yang paling cepat mati setelah diinfeksi dengan bakteri $A$. hydrophila adalah sidat dengan perlakuan tanpa diberi dosis bakasang. Muncul berupa kemerahan atau hiperemia pada insang dan operculum. Gejala kemerahan pada insang dapat berbentuk bercak, terutama pada keseluruhan bagian tubuh. Kemerahan dapat juga terlihat menyebar merata. Gejala klinis lainnya yang terlihat jelas adalah pergerakan ikan menjadi lamban dan nafsu makan menurun. Gejala tersebut merupakan manifestasi klinis $A$. hydrophila (Gambar 1).

Menurut Yardimci dan Aydin (2011) ikan yang terinfeksi A. hydrophila menunjukkan gejala klinis sesuai dengan lama waktu terjadinya infeksi. Namun secara umum gejala yang terlihat setelah 8 jam diinfeksi adalah adanya bercak merah pada kulit atau sisiknya. Gejala penyakit bercak merah ini ditandai dengan adanya lesi sampai ulkus, sisik mudah terkelupas, bercak merah pada seluruh tubuh, insang 
berwarna suram atau kebiruan, exopthalmia (bola mata menonjol keluar), pendarahan pangkal sirip punggung, dada perut dan ekor, juga terjadinya prolapsus dan pendarahan pada anus, oedema abdominal yang disertai dengan adanya transudat berwana kemerah-merahan, hilang nafsu makan, gangguan keseimbangan tubuh, dan akhirnya mati. Yin et al. (2008) melaporkan bahwa ikan nila yang diinfeksi $A$. hydrophila akan mati dalam waktu 3-4 hari setelah infeksi terjadi.

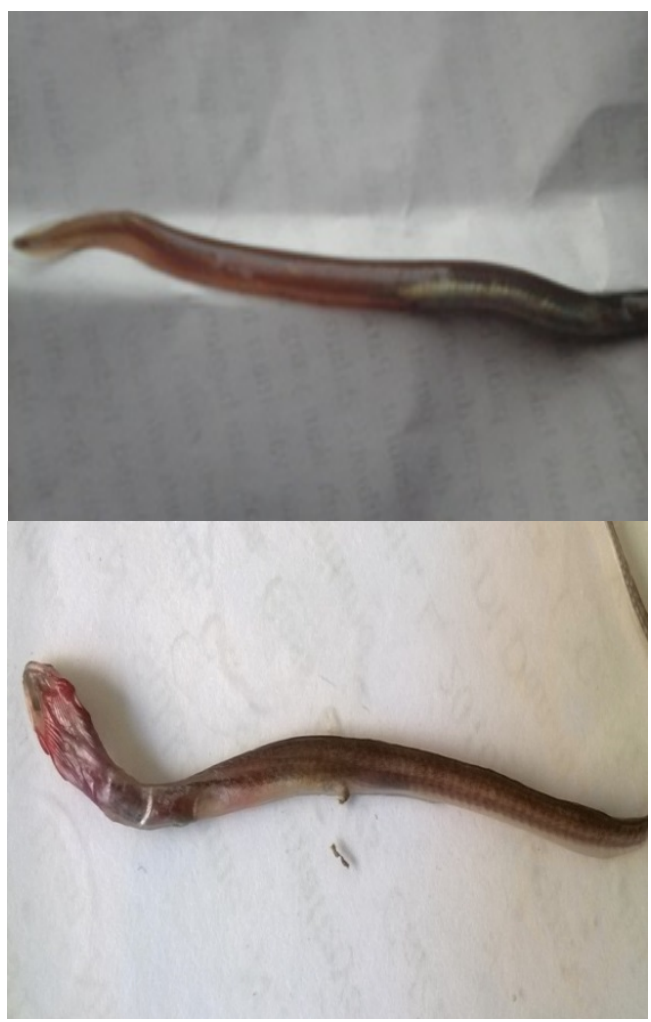

Gambar 1 . Sidat yang terinfeksi

\section{A. hydrophila}

\section{Pertumbuhan}

Pertumbuhan mutlak sidat yang diberi perlakuan bakasang setelah enam minggu masa pemeliharaan dapat dilihat pada Gambar 2.

Data pertumbuhan diukur pada akhir periode pemberian pakan perlakuan sedangkan data mortalitas sidat diamati selama 10 hari setelah uji tantang. Hasil Analisis ragam menunjukan bahwa resistensi sidat pada perlakuan B (50 $\mathrm{mL} / \mathrm{kg}$ pakan), C (100 mL/kg pakan) dan D $(150 \mathrm{~mL} / \mathrm{kg}$ pakan) berbeda nyata dibandingkan dengan perlakuan A. Namun demikian, antar perlakuan B, C dan D tidak terdapat perbedaan nyata. Selanjutnya pertumbuhan sidat terbaik diamati pada perlakuan $B$ dengan pertumbuhan mutlak $1.14 \mathrm{~g}$, diikuti pada perlakuan D dengan pertumbuhan mutlak 1.04 g. Pada perlakuan A pertumbuhan mutlak hanya sebesar $0.82 \mathrm{~g}$ sedangkan pada perlakuan $\mathrm{C} 0.88 \mathrm{~g}$.

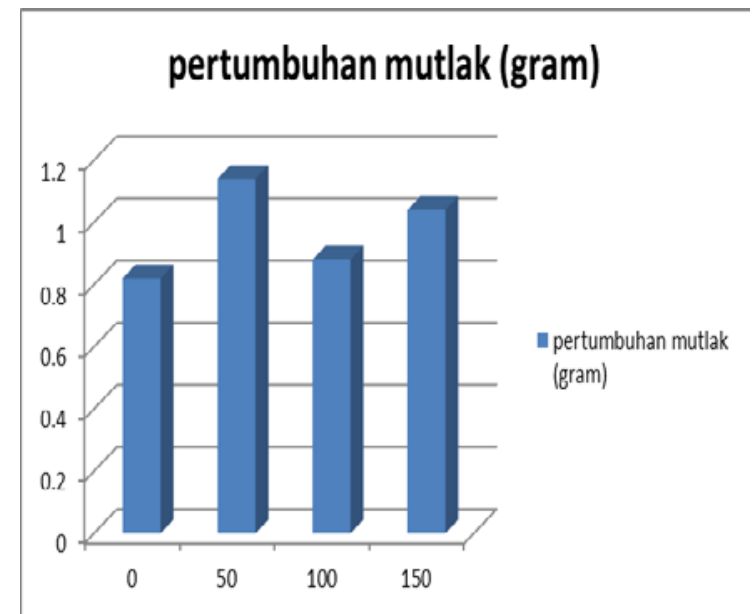

Gambar 2. Grafik pertumbuhan mutlak sidat

\section{KESIMPULAN}

Berdasarkan hasil uji tantang dengan bakteri aeromonas hydrophila menunjukan bahwa penambahan bakasang dalam pakan sidat dapat meningkatkan pertumbuhan serta resistensi sidat terhadap infeksi patogen.

\section{DAFTAR PUSTAKA}

Anderson DP. 1992. Immunostimulants, adjuvants and vaccin carriers in fish : applications to aquaculture. Annual Rev. Of Fish Disease. 2 : 281- 307. 
Effendie MI. 1997. Biologi Perikanan. Yayasan Pustaka Nusatama. Yogyakarta.

Gatesoupe FJ. 1999. The use of probiotics in aquaculture. Aquaculture 180 : 147-165.

Ijong FG, Ohta. 1996. Psyhochemicaln and microbiology changes associated with bakasang. Processing - a traditional Indonesia fermented fish sauce. Laboratory of Microbial Biochemistry. J. Sci Food Agri. 71, 69-S74

Ingratubun JA, Ijong GB, Onibala $\mathrm{H}$. 2013. Isolation and identification of lactic acid bacteri in bakasang as fermented microbe starter. Aquatic Science \& Manajemen, Edisi Khusus $1,48-56$

Efriansyah F. 2009. Karakteristik kandidat bakteri probiotik dari ikan sidat (Anguilla bicolor) sebagai anti Aeromonas berbasis analisis molekuler. Skripsi. Universitas Padjajaran. Bandung.

Koroh PA, Lumenta C. 2014. Pakan suspensi daging kekerangan bagi pertumbuhan benih sidat (Anguilla bicolor). Jurnal Budidaya Perairan Vol.2 No.1:hal 7-13

Pinoke S, Tumbol RA, Kolopita M. 2015. Penambahan bakasang pada pakan benih sidat (Anguilla marmorata) untuk meningkatkan sistem imun non spesifik. Jurnal Budidaya Perairan Vol. 3 No. 3: 12-18.
Pangaribuan RD, Tumbol RA, Manoppo H, Sampekalo J. 2013. The role of bakasang as immunostimulant on non-specifice immune response in Nile Tilapia (Oreochromis niloticus), Aquatic Science \& Management (Jurnal Ilmu dan Manajemen Perairan). Vol.1, No 2: 78:491-497.

Sidatmoa. 2009. Kandungan gizi ikan sidat. http://sidatmoa.wordpress.com /2009/08/04/ kandungan-gizi-ikansidat/. (Download 06/03/2016).

Yanti, Indah, Dwi, Widya. 2009. Skrining bakteri asam laktat sebagai probiotik potential diisolasi dari bakasang. Thesis. Program Pasca Sarjana Universitas Sam Ratulangi, Manado.

Yin G, Ardo L, Jeney Z, Xu P, Jeney G. 2008. Chinese herbs (Lonicera japonica and Ganoderma lucidum) enhance non-specific immune response of tilapia, Oreochromis niloticus, and protection against Aeromonas shydrophila. In Diseases in Asian Aquaculture VI. BondadReantaso, M.G., C.V. Mohan, M. Crumlish, and R.P. Subasinghe. (Eds.). Fish Health Section, Asian Fisheries Society, Manila, Philippines 